Author: Dr Pippa Virdee

Institutional affiliation \& postal address: De Montfort University, the Gateway, Leicester, LE1 9BH (UK)

Telephone number: + 44 (0) 1162078595 Email: pvirdee@dmu.ac.uk

Short biographical note: Dr Pippa Virdee is Senior Lecturer in Modern South Asian History in the school of Humanities at De Montfort.

Keywords: Pakistan, Women, Aviation, Cold War, PIA

Word-count: 12,115 (incl. end-notes) 


\section{Women and the Pakistan International Airlines in Ayub Khan's Pakistan}

This article weaves together several unique circumstances that inadvertently created spaces for women to emerge away from the traditional roles of womanhood ascribed to them in Pakistan. It begins by tracing the emergence of the Pakistan International Airlines (PIA) as a national carrier that provided an essential glue to the two wings of Pakistan. Operating in the backdrop of nascent nationhood, the airline opens an opportunity for the new working women in Pakistan. Based on first-hand accounts provided by former female employees, ${ }^{1}$ and supplementing it with official documents, newspaper reports and the advertising used for marketing at the time, it seeks to provide an illuminating insight into the early history of women in Pakistan. While the use of women as markers of modernity and propaganda is not new,${ }^{2}$ here within the context of Cold War and American cultural diplomacy, the 'modernist' vision of the Ayub-era in Pakistan (1958-69), and its accompanying jet-age provide a unique lens through which to explore the changing role of women. The article showcases a different approach to understanding the so-called 'golden age' of Pakistani history: a neglected area of the international history on Pakistan, which is far too often one-dimensional. ${ }^{3}$

\section{Introduction}

The decades of 1950s and 1960s in the young nation-state of Pakistan were looked upon as an opportunity to decolonise the mind and body and realise the long sought-for selfrepresentation, from colonial times. ${ }^{4}$ These early years offered a chance to the partisans and participants of the Pakistan movement, now proud citizens of a homeland for the Muslims of India, to establish it on a firm, global footing. ${ }^{5}$ For the 'ordinary, progressive and radical' among them, there was hope 'of forming a society in which they would have a place and a voice'. ${ }^{6}$ For the women among them, this was an opportunity to build on the previous small inroads made during the Pakistan movement. ${ }^{7}$ The founding father of 
the demand for Pakistan and the leader of the All-India Muslim League, Mohammad Ali Jinnah, had encouraged women to engage in Muslim politics and embrace the nationalist movement. ${ }^{8}$ This meant coming out of $\operatorname{purdah}^{9}{ }^{9}$ and the Muslim League was successful in mobilising limited support for this. ${ }^{10}$ It became imperative to engage women and make them part of the nation-making project when, apart from politics, they emerged as essential in the rehabilitation of millions of refugees, who flocked to the 'Muslim Zion' in $1947-8 .{ }^{11}$

A lesser-worked aspect of the history-writing on the emergence of Pakistan, which is either India-centric or Islam-centric with exceptions, ${ }^{12}$ this contained within its folds the crucial roles played by women, especially working women, at this time. ${ }^{13}$ Largely confined to the home until then, their engagement, even if in 'respectable' professions such as teaching, nursing, or medicine, emerged as valuable for the new nation-state, for whose social consolidation and cultural cohesion, educated women were an essential component. ${ }^{14}$ In the census of 1951, professional and technical categories $(10,501 ; 0.08 \%)$, administrative employers $(2,829 ; 0.21 \%)$ and sales workers/ shopkeepers $(29,729 ; 2.26 \%)$ returned minuscule numbers. Women have always worked in rural areas in the cultivation of land, agrarian areas like the parts of Punjab that became Pakistan were no exception, ${ }^{15}$ and in 1951, the number of agricultural workers amounted to $1,016,913$ or $77.24 \%$ of total number of working women and girls. Simultaneously, there slowly emerged a class of urban working women, as the post-colonial state of Pakistan started to be set-up. ${ }^{16}$ In the first four years of Pakistan's existence, more than $5 \%$ or over 70,000 women were listed as skilled workers and unskilled labour each, while the number of domestic servants was over 50,000 (3.84\%). It is against this backdrop that Pakistan International Airlines (PIA) played an important part in liberating urban women 
from traditional occupations and offering them an exciting opportunity to explore the world, ${ }^{17}$ in the process becoming a part of the-then emerging image of 'Asian Modernity' through aviation. ${ }^{18}$ As Kathleen Barry has shown in her history of flight attendants in the United States that it is 'a story in which glamorization and organization, and femininity and feminism, uniquely shaped the efforts of a cultural elite among working women to claim greater respect', ${ }^{19}$ so for Pakistan, PIA offers a lens through which we can understand this process taking place.

The advertising used to recruit women by PIA is particularly illuminating because we can get a sense of the changes taking place within the wider social-cultural milieu of a consolidating Pakistan. ${ }^{20}$ As the airline was/is state-owned, its advertisements represent the statist self-image presented internationally as well as for public consumption in Pakistan. The airline was emblematic of Pakistan as an emerging nation. For the historian, 'making sense' of these 'discursive' advertisements provide an insight into the changing social cultural landscape of women in public spaces during the formative years of Pakistan's history. ${ }^{21}$ The women working for PIA personify therefore a prism through which to examine both their changing role in the work place and, more broadly, the public and 'official' representation of women. More broadly, their remembrances help recover the 'middle class modernity' of early Pakistan, ${ }^{22}$ as in the words of Keith Lovegrove, 'the stewardess became the public face of the airline, [its] embodiment [and so] how [they] looked began to become increasingly important'. ${ }^{23}$ This microcosmic case-study thus provides a vantage from where we can throw light on some of the over-shadowed complexities in Pakistan's formative years and how they form part of a nostalgia for that 'golden age' in the present day. ${ }^{24}$ As 'the "Nisei" stewardess' presence as the Asian (American) woman aloft helped to solidify Pan American's position as "the world's most 
experienced airline"", ${ }^{25}$ so the presence of women in PIA helped establish it as one of the most respected 'Third World' airlines of the 1960s. And, just as Pan Am in 'The Jet Age' was seen as a 'particularly American public servant', so PIA can be seen as 'reinscribing the nation' for early-Pakistan. ${ }^{26}$

PIA's flights begin inside a decade from the Partition of India providing an image of boundlessness for a fractured, moth-eaten nation that went beyond its boundaries. Akin to how the 'Nisei pioneers' of 1955 , who self-consciously paved the way for others, the first PIA women felt similarly about themselves: 'as having left the safety of home to travel the world' ${ }^{27}$ This article therefore knits together three separate threads namely first the context of national ideology in an era of emergent globalism following Partition; second, culture and the complex ways in which it complicated gender roles and third the cosmopolitanism symbolised by modern aviation industry. It thus steers clear of the accepted narratives of early Pakistani history and, in their stead, attempts a multi-sited account of its social milieu. In terms of its sources, it relies primarily upon oral histories of PIA's women workers thereby juxtaposing personal experiences with primary archives, secondary publications, and the popular press. In doing so, it follows recent relevant works in showing 'the ways women navigated their often unexpected upward class mobility and global education they gained while flying', and, 'the manner in which they attempted "carving out their own sense of self" within national-corporate frameworks'. ${ }^{28}$

\section{'Taking Off to a New Dawn'}


In 1963, Ed Mack Miller, a flight instructor on lease to PIA, penned his experience in Flying, the aviation magazine. He observed that PIA 'serves one of the most unusual purposes of any airline in the world that of holding a nation together...if there were no PIA, the 15-year-old country of Pakistan might fall to pieces' ${ }^{29}$ Air transport was thus one of the more important considerations for the development of Pakistan as a nationstate, given that territorially the country was fragmented and far-apart and a 'flying' connectivity was an absolute imperative, 'otherwise what was a geographic division could well have become a national cleavage'. ${ }^{30}$ The train service that ran between the provinces of West/East Punjab and East/West Bengal, as well as Sindh and Rajputana, was discontinued following partition and its horrific aftermath of trains being ambushed and people being burnt alive as they fled to reach the other side of the border in and from August 1947, eventually resulting in one of the largest population transfers of twentieth century. ${ }^{31}$ The other alternative was sea travel, connecting Karachi in the West with Chittagong in the East, a journey that typically lasted seven to ten days. Air travel instead, despite having to go through a hostile Indian air-space, meant a journey of eight to nine hours between Karachi and Dacca. ${ }^{32}$ Logistically, economically and practically then, the development of air travel was a crucial component for the Pakistan state from its conception. Indeed, it would not be an exaggeration to say that PIA served as an essential glue that kept the two distant, disparate wings connected.

That this fact was recognised can be seen when tracing the history of PIA, which goes back to pre-partition days when Pakistan was being imagined. Indeed if 'Pan American World Airways provides an excellent case study of empire building', then PIA provides an example of nation building with the airline as the 'nation's "chosen instrument", ${ }^{33}$ Enver Jamall, former chairman and chief executive of PIA, remembered 
that the idea of a Muslim-owned airline was suggested by Jinnah as early as February 1945, since it was inevitable that any territorial division would result in 'a truncated Pakistan' ${ }^{34}$ Despite talks of a corridor to link the two wings, from their birth, they were divided by over 1,100 miles of Indian Territory. Jinnah had been thinking about commerce and industry - including aviation - in a future Pakistan, and it was here that he turned to the Ispahani brothers, Mirza Abol and Mirza Ahmed; well-established and prominent industrialists from the Muslim community in undivided Bengal. ${ }^{35}$ Among early supporters of the Pakistan movement, Jinnah requested the Ispahanis 'to set up a national airline on priority', ${ }^{36}$ even as the nation was yet to be set-up. In June 1946, Jinnah had posed challenging questions of the Ispahanis:

\footnotetext{
It is all very well to talk of Muslims as nation and to demand a separate homeland for them, but such a State would be useless if we did not have the men, the material and the wherewithal to run it? Do you realize that in India there is not a single airline which is owned or operated by Muslims? Do you know how many Muslim pilots and mechanics we have in the country? How can we do anything with this inadequacy of material ${ }^{37}$
}

Jinnah had a valid point. In 1939-40, the four existing Indian airlines were the Bombay-based Air Services of India, Delhi-based Indian National Airways, Calcuttabased Indian Transcontinental Airways, and the flamboyant Tata Sons. ${ }^{38}$ The last among these, which would go on to become Air India in 1946, was the first to begin on 15 October 1932. Interestingly, Genell Moots of TWA came from Kansas City to train its first batch of air hostesses. ${ }^{39}$ By 1945-6, fifty-one applications were received from ten companies for thirty-seven air routes in post-war British India, ${ }^{40}$ one of which was by the Jinnah-inspired Ispahani Brothers for Orient Airways, which got established on 23 
October 1946. It purchased the first set of planes in February 1947, received its operating license from the Interim Indian Government in May and commenced operations on 4 June 1947 on the Calcutta-Rangoon route; incidentally, a day after the Partition Plan was announced. Within two months, Pakistan came into being and, initially, the Government of Pakistan chartered aircraft from British Overseas Airways Corporation (BOAC), in addition of Orient Airways, to assist in relief and rehabilitation operations. As Mirza Abol recalled with an owner's pride:

It was Orient Airways, which rendered yeoman service during the disturbances which followed Partition. It brought Muslim refugees from India and flew out Hindus from Pakistan; had it not been for the Orient Airways, there would not have existed an air link between East and West Pakistan, for a long time after Partition. ${ }^{41}$

Flights were operating between major cities but it is fair to say that these fliers, distinct from refugees, would have been politicians, officials, press and businessmen. Moreover, Orient Airways was still rather skeletal, as it relocated to Karachi and the first scheduled operations from there started in January 1948. The initial routes were: KarachiLahore-Peshawar, Karachi-Quetta-Lahore and Karachi-Delhi-Calcutta-Dacca; and from the Calcutta base, Calcutta-Akyab-Rangoon, Calcutta-Dacca and Calcutta-Chittagong. ${ }^{42}$ By the end of 1949, the Orient had thirteen planes running on these six routes. The growing demand for air travel was illustrated by an advertisement in the Pakistan Times from 6 August 1950 with the following tagline about the upcoming 'vital air link between Lahore and Dacca', which was to go via Delhi and Calcutta. 
Reflecting this rising tide, two other privately owned airlines, Pak Air Limited and Crescent Airways, were started but neither could sustain and BOAC were allowed increased traffic rights. ${ }^{43}$ By now, it was also becoming clear that Orient was reluctant to invest any further in a growing project, which albeit was still returning loss. Equally the growing needs made imperative the generation of additional capacity and it was decided in 1951 to establish a national airline. From October 1953, government of Pakistan steadily moved to form a state-owned airline and invited Orient to merge with it. In June 1954, PIA had its inaugural run on the Karachi-Dacca route, with this direct service reducing the flying time from nine to six hours, and the ordinance laying its birth was promulgated in January 1955. The following month, it flew its first international flight, from Karachi to London via Cairo. In March 1955, PIA formally took over the fleet and routes of Orient, thereby concluding the latter's fairy-tale existence and thus consolidating itself. ${ }^{44}$ Meanwhile, across the border, Air India had been recognised as India's 'designated flag carrier' in 1948. The Government of India took a 49\% stake in the company, retaining the option 'to purchase a majority interest' and gave a ten-year management contract to JRD Tata. In 1953, it had bought 'the remaining stake' and an Air Corporations Act was passed 'nationalizing the aviation industry' ${ }^{45}$ In similar ways then, these airborne dreams addressed 'both the possibilisms and problematics of a dreaming nation within them' ${ }^{46}$

For PIA, the following five years (1955-60) saw a major development programme sponsored by the Ministry of Defence, at a total estimated cost of Rs. 1,004 lakhs. ${ }^{47}$ It was always recognised that 'the development of this mode of transportation [was] important because of the great distance between the two parts of the country' and the programme was to enable the airline 'to meet an urgent requirement'. ${ }^{48}$ The government's 
initial support can be gauged by the fact that in the second-half of 1954, the bills of subsidy to PIA amounted to Rs. $467,150 .{ }^{49}$ It was being 'paid for all passengers travelling by the PIA on Karachi-Dacca and Lahore-Dacca routes, irrespective of their nationalities'. ${ }^{50}$ By May 1956, PIA bills presented for payment had shot up to Rs. sixteen lakhs. ${ }^{51}$ By early 1958, PIA was planning to operate ten-twelve flights a week between Karachi and Dacca, ${ }^{52}$ four flights a week between Lahore and Dacca, as well as considering services between Rawalpindi/Karachi and Delhi and Dacca-LalmonirhatSylhet. ${ }^{53}$ Consequently, staff requirement continued on an upward curve; from little over 2,000 in 1956 to 4,000 personnel in $1959 .{ }^{54}$

In March 1959, Air Commodore Malik Nur Khan was appointed as the second managing director of PIA thus bringing the airline firmly within the fold of the defence establishment. This was an outcome of the emergence of General Muhammad Ayub Khan, Commander-in-Chief of Pakistan Army since 1951, as chief martial law administrator in October 1958, later legitimised as President by a referendum in 1960. Ayub remained in power until 1969 and his period, heralding 'military politics' or the state of 'martial rule' in Pakistan, ${ }^{55}$ is also synonymous with modernisation, albeit forced, and prosperity, albeit fragmented. ${ }^{56}$ It is a period in which Pakistan appears to be at ease with its identity and as Marcus Daechsel argues, 'more than anything else, Pakistan felt respected in the world', despite the failures/stalemate of the 1965 war with India and increasing political discontent in the then-East Pakistan. ${ }^{57}$ In other words, Ayub Khan's Pakistan, 'the first military regime' for the country, was akin to 'the end of the beginning' - uncertain and fragile - of the country in $1947 .{ }^{58}$ A key factor in this consolidation of the Pakistan nation-state, ${ }^{59}$ was its close ties with the United States of America (US), 
symbolised by the 'pact-politics' of 1950 s in the 'Global Cold War' ${ }^{60}$ Pakistan received economic, technological, agricultural and military assistance; indeed, it was put 'on the flight path of American power'. 61

Despite later and recent disenchantments, ${ }^{62}$ this early 'alignment with the West',${ }^{63}$ had significant impact on PIA. In 1961, with a leased Boeing 720B, 'PIA held, for a short while, the distinction of operating the longest-ranged airliner in the world' ${ }^{64}$ Three years later, in April 1964, much to the dismay of the Americans who, in retaliation, cancelled financial aid to build the new airport at Dacca, PIA became the 'first non-communist airline to fly to the People's Republic of China', from Dacca to Shanghai via Canton. ${ }^{65}$ This route, occasioning an advertisement of 'another PIA exclusive: package tours to China' in the Pakistan Times of 4 August 1964, was dependent on its Dacca hub, which would be lost in $1971,{ }^{66}$ and play a role in the decline of the airlines.

However, establishing a national airline was one thing, to nationalise it and encourage nationals to use it were different matters. In August 1960, Ayub Khan directed the Ministry of Defence to 'suggest measures for ensuring that Pakistani national travel by their national airline'. Among these were that 'all government servants should be ordered to travel PIA and Pakistani businessmen going abroad should be given travel costs by the State Bank only if they travel PIA' ${ }^{67}$ In the following month, a major note was prepared that summed up the scenario since the beginning:

\footnotetext{
Training is one of the biggest problems...Due to projected expansion, the staff strength will have to be raised to 4200 by 1960 , when the capacity operated by PIA will have increased to about 48 million ton-miles: a 200\% [increase from] 1957. For this [a] [ground] training school has been set-up. A Scheme for Technical Aid is in operation... Since there was a
} 
dearth of trained airline personnel in Pakistan, PIA had to employ a number of foreign staff. As Pakistanis are trained, they replace the foreign staff. A good deal of nationalization has already taken place and it is hoped that by 1960 the airline will be completely nationalized. ${ }^{68}$

At the end of the first three years of Nur Khan's tenure, PIA employed 7,000 personnel, of which 144 were pilots and thirty-eight were flight engineers. Its 'flight kitchen' was not only preparing 30,000 meals per month but was also 'providing catering services to four other international airlines' ${ }^{69}$ With its 'in-flight film shows for both first and economy class', 'choices of Pakistani or Western cuisine', punctuality and 'oriental grace', ${ }^{70}$ and the troika of Nur Khan, Enver Jamall and chief inspector Syed Aijaz Ali, PIA impressed the aviation experts flying in from far-and-wide as 'great chaps', with whom it was 'a privilege' to work. ${ }^{71}$ Indeed, one of the most popular stopovers during this golden age of glamour in the skies was in Karachi, with accommodation near the airport and 'best breakfast at any time of the day' being served by 'bearers - always so smart and proud in their white uniforms'. ${ }^{72}$ Karachi appeared 'redolent of Graham Greene and Rudyard Kipling', at a time 'when flying was embarked upon with a pioneering spirit that dwelt in those modest establishments'. ${ }^{73}$ Of course, this 'modernity...was shared unevenly by groups, depending on their class, status, proximity to power, and race or ethnicity. [Then], the genders participated differently...'74

Jamall notes the competition PIA had with Air India, which had already placed orders for Boeing 707s to be delivered in 1960 . However, there was much determination within PIA to be the first airline in the east to operate jets and so an agreement was reached with Pan American Airways for the lease of one of its Boeing 707s. This would operate on the London-Karachi-Dacca route, with an extension to New York once a week. The flights began in March 1960, giving PIA the coveted first and the route was a 
financial and operational success, especially with its much-remarked 'superb cabin service'. ${ }^{75}$ In comparison, Air India took delivery of its first Boeing 707-437 on 21 February 1960, but by June 1962, it was an 'all-jet airline'. ${ }^{76}$ Nur Khan was followed by another Air Marshal, Asghar Khan, and taken together, their decade at the top of PIA, inextricably linked with the country's leadership of Ayub Khan, was often proclaimed as the airline's 'golden age', ${ }^{77}$ as in a special issue by the Pakistan Times on 14 August 1962.

\section{'The Finest Way to See the World'}

When PIA started operations, its 'newness' made it inevitable that foreign personnel had to be recruited to address the gaps in the industry. There was however, from as early as 1948, 'a policy of developing training facilities and attaching local personnel as understudies or sending them overseas' and 'an Airways Training Centre was organized at Karachi and a Communication School was added'. ${ }^{78}$ Given the 'growing public and corporate opinion that attending people in the air was "women's work", ${ }^{79}$ and its growing identification with 'middle-class ideals of femininity', ${ }^{80}$ the early years of aviation in Pakistan are also a good lens to analyse the politics of gender roles. Thus, while in the interim, foreigners and a small number of Pakistani girls filled the vacancies of airhostesses, ${ }^{81}$ advertisements were placed in newspapers like the Pakistan Times to recruit more girls. In 1951, in Air Transport there were only eleven women, soon in PIA alone there were seventy-six women employees. By 1960s, the batches were girls-only, about twenty strong, with an overwhelming number from Lahore. ${ }^{82}$

This was not accidental and further attests to the presence there of a 'colonial middle class' turned 'nationalist bourgeoisie', whose upper echelons were inflecting 
'national culture' with their 'ashraf etiquette and progressive sensibilities' that 'converged with the ideals of modernization theories, which enjoyed international support at the time'. ${ }^{83}$ By 1971, it was getting 'difficult to join the airline'. Over 400 girls were interviewed that year in Rawalpindi itself, with only seven reaching the final round held in Karachi. Eventually, only three were selected, showing the rising standards of the PIA's recruitment. ${ }^{84}$

However, this had been neither easy nor straightforward. A report in the Pakistan Times from 4 November 1951 titled 'for women who want to work', began positively that it was 'no longer possible to prevent [them] from marching towards emancipation and economic independence', before listing the hurdles: 'lack of education, purdah, early marriage, prejudice and limited opportunities'. An employment exchange superintendent recalled that 'Partition brought a tremendous [number] of women deprived of all support into her office [saying] "give us any work". Some had skills, majority were untrained or illiterate [but] Purdah [was] the chief problem'. Almost five years later, on 23 September 1956, the paper carried another article 'about women traveller', which began gushingly about 'rapidly changing times': 'Gone are the days when women could not move unchaperoned, for now they travel the globe...paths yet untrodden by women'. The article went on to detail the account of six girls from Punjab University, who went through Kafiristan and Chitral, calling them, 'in their own small way, pioneers'.

To tap into this expanding women's world, it was necessary to make 'travelling her job'. The theme of using attractive stewardesses to promote airlines began in the mid1950s, when Anne Price, competing against stewardesses from other airlines, was chosen as 'Queen of the Air'. ${ }^{85}$ In Keith Lovegrove's words, stewardesses quickly became the 'supermodels of their day'. ${ }^{86}$ In July 1962, a profile appeared in the Pakistan Times of 
Khurshid, who worked for one of Lahore's biggest travel agencies. Describing the life of the working woman, with four little girls, it invited others by pointing that 'business-like yet charming Khurshid knows the world now, since there is hardly a corner of it which her tickets have not covered' ${ }^{87}$ A reminder of the 'progressive past of Lahore' and its 'lost culture', the profile is a glimpse into the 'old middle class' there, much before the onset of the current 'personalized pieties of the new middle class' ${ }^{88}$ The following is the text from another such advertisement from July 1964 that invited 'applications from unmarried girls for the posts of flight stewardess/air-hostess':

AGE 21-26 YEARS. MINIMUM HEIGHT 5'2”. WEIGHT BETWEEN 100-135 LBS [45-

61KG]. EDUCATION MATRICULATE. SHOULD SPEAK ENGLISH AND URDU/BENGALI. SELECTED CANDIDATES WILL BE REQUIRED TO UNDERGO TRAINING AT KARACHI FOR 12-16 WEEKS...SALARY OF RS. $470.00{ }^{89}$

Kathleen Barry has explored 'how ideas about glamour affected who was hired and what kinds of expectations airlines had of [these] women'. ${ }^{90}$ A PIA advertisement from 1966, featuring two female employees, with accompanying pictures from Istanbul, Cairo and Frankfurt and an expansive text, nicely illustrates it:

THE FINEST WAY TO SEE THE WORLD! Join PIA as an AIRHOSTESS! Age 17-26 years; Reasonable proportion between height and weight; Education matric. Able to speak English and Urdu or Bengali. Unmarried. Initial SALARY-Rs. 510.00, Jet allowance Rs. 100.00, Pocket allowance Rs. 100 p.m. ADDITIONAL BENEFITS-Free accommodation in a first-class hotel with an allowance of $£ 3 / 10$ per day when abroad. Free accommodation and food in first class hotel when travelling within Pakistan. Hostel facilities at subsidized rates 
in Karachi. Concessional travel facilities for parents. Medical facilities. Free hair styling.

Transport to and from the place of duty. ${ }^{91}$

As can be seen, the age limit was lowered so that it could attract more girls into the profession. The 'unmarried' clause remained and this was a requirement not just for PIA, but with other international airlines too at the time. Victoria Vantoch notes how in America, airlines' 'managers hired only single women, portrayed the work as training for the future role as wives, and required stewardesses to resign upon marriage. Some even had the maximum age limit of $32{ }^{\prime} \cdot{ }^{92}$ Phil Tiemeyer shows that it was found 'economically convenient' to have these 'punitive rules for women...which meant a fairly constant flow of "pretty" young women at the lowest possible pay'. ${ }^{93}$ Elsewhere, this dichotomy has been articulated as the stewardess reflecting in the 1950s the image of the 'glamorous brides in waiting: perfect wife'; 'part mother, part geisha'. ${ }^{94}$ It is also clear that girls had to be educated, with the essential ability to speak English and Urdu/Bengali. As we shall see from the personal accounts of women, who worked for PIA, many of them joined it because of these attractive advertisements, with its tempting terms.

Travelling abroad was an aspirational luxury for an elite group of Pakistanis and while the foreign tourist market was crucial, in March 1960, Ayub Khan's cabinet directed the Ministry of Defence to look into the passenger traffic on domestic and diaspora routes, with an aim to increase it between regions and across groups. ${ }^{95}$ In 1955 , when the first fight 'to the glittering London, via Cairo and Rome' had started,${ }^{96}$ it had invited some criticism from those who regarded other projects as more urgent for a developing country like Pakistan. The response had highlighted the substantial foreign exchange earned through this international service. ${ }^{97}$ Thus an advertisement published in the Pakistan Quarterly in spring 1960 had the tag line 'Move with the Times: Fly PIA'. 
The accompanying picture was of two foreigners, sitting in first class and being served wine and food. The appeal to the foreign market was evident and included placing advertisements in French in foreign publications. The airline was establishing a reputation for excellent service and was steadily 'flying high' in the international air-space in the 1960s. ${ }^{98}$

Unsurprisingly, for the women who worked, these international routes were the most sought after. In her interview, Naheed Talat who joined PIA at the age of eighteen in 1966 and worked there for twenty-eight years, exclaimed on the hierarchy and prestige of different routes:

\footnotetext{
In that era, international flights had certain standards. Initially, people would go to Saudi Arabia, Gulf and then Europe, America [and] the pearl-routes PIA started - to Japan...I used to love them - going abroad, enjoying ourselves, seeing the world, and travelling is the biggest education one can get. No university degree can teach you. ${ }^{99}$
}

This echoes what Christine Yano found out in a relatable context, that the experience was like 'getting a master's degree in the world...being an important part of the national scene as it extended to other parts of the world'. ${ }^{100}$ Naheed remembers getting 'a lot of foreign offers in those days [from] newly developed airlines'. Saudi Airlines especially used to offer opportunities and many PIA 'girls did go to Saudi Airlines'. Naheed always declined, saying 'we were so proud of PIA and Pakistan'. Similarly, Emirates Airlines did not exist then and PIA used to take care of their needs. Heads of Gulf States and their royal families used to come to Pakistan and Naheed recalls working on one of the flights that 'brought Queen Fatima and all the females'. Mixing girls 'from humble background with General's daughters', bringing together Anglo-Indian girls with 
Pushto, Sindhi and Balochi girls, PIA offered financial security, a fascinating attraction and 'was the easiest way out' for all. ${ }^{101}$ For Rukhsana Majid (Pixy), who joined the airline in 1971 and left in 1981, 'PIA was like mini Pakistan'. ${ }^{102}$ The image of the airhostess, not least because of what the job specification required, was that of a young lady, who popularly represented a sophisticated, cosmopolitan and independent individual; in short, an icon. As Vantoch notes in the American case, these were 'ambitious career woman employed on the cutting edge of technology', ${ }^{103}$ and breaking through traditional gender roles. This applies to Naheed, Rukhsana and others in Pakistan too.

Whereas Vantoch's argument has centred on how the image of the all-American, wholesome yet glamorous stewardesses was used in its propaganda in the Cold War, ${ }^{104}$ unlike women from the former Soviet Union who were represented as manly, ${ }^{105}$ in PIA's case it was about presenting an idealised vision of a realised nation. Pan Am's president Juan Trippe called international air travel 'an important contribution to the [American] economy' and a 'strategy in selling the U.S. and [its] "way-of-life" to other nations'. ${ }^{106}$ An example of this from PIA's advertisements comes from the 1966 tagline, 'Pakistani girls make good Daughters - no wonder they make such good Hostesses' ${ }^{107}$ The advertisement depicts a young, elegant lady playing with a child on board a flight and continues: 'Affection for the young, respect for elders and the desire to be helpful, hospitable and gracious...make-up of every daughter of Pakistan'. These attributes can easily be applied to any 'good' daughter-in-law. As Naheed confirms 'in that era after you married, you had to leave flying at least - not the ground staff'. ${ }^{108}$ Pixy 'did not want to leave' her job but 'because [her] husband did not want [her] to work', as a 'Pakistani girl' she relented but continued to 'miss it a lot' and, along with it, her 'independence....and life'. ${ }^{109}$ 
Apart from reflecting home, the PIA air-hostesses were also representing Pakistan in world, and were, often, the first point of contact that a foreign visitor would have with Pakistan. And so, advertisements tried to legitimise the role of the air-hostess as a 'respectable' profession; thereby quelling any parental fears for their daughters wanting to join. Finally, the use of glamorous young females in exotic locations promoted an image of Pakistan that was modern, progressive, internationalist and welcoming. This duality is well-recalled by Pixy, for whom, the most memorable highlights comprised 'travel to different places, chance to meet different people, [being] together [with] the crew, [which] never [gave] a chance to miss our families'. ${ }^{110}$ This also chimes with Drew Whitelegg's observation that flight attendants working the skies often liked 'to claim a neat separation between work and home'. ${ }^{111}$

By 1966, more things had changed, though this change was gradual rather than revolutionary. An article by Camille Mirepoix in the Pakistan Times noted that the thought of women leaving their home to work outside was shocking. However, this was only as shocking as, for example that fifty years ago people were shocked by artists and actresses, who were then considered 'unrespectable'. So, while husbands and fathers frowned upon women working, they were beginning to accept more 'respectable' professions such as a lady doctor or a nurse. It notes how, 'the field was so limited that females in the poorer and middle classes had no opportunities at all'. And, it was here that the demand for air-hostesses, made by PIA, began to make cracks upon social structures. ${ }^{12}$ Not that it proved easy or straightforward, for Mirepoix lamented that, 'in spite of rosy offers of good salary (more than a hard-working male typist could earn) the supply was limited. Many young ladies applied, were accepted, trained and prepared to start when their families put a stop to it'. Still, those who could and did were, to all extent 
and purposes, breaking new ground and deserve to be placed within the 'cartographies of struggle' that 'Third World Women and [their] Politics of Feminism' waged. ${ }^{113}$ Indeed, it is a testament to those times that a small number of women managed, many eventually with the support of family, to move away and work for PIA, which gave them opportunities to travel the world.

\section{Branding the Nation: Style, Glamour, and Charisma}

In terms of the visual appeal of advertisements for recruitment, be it enlisting masculinity or femininity, ${ }^{114}$ the uniforms, be they of military or airlines, were never just a matter of practical apparel. Increasingly, they came to symbolise the 'brand' of that nation; an image to be etched on the customers by the staff wearing them. Moreover, invoking military prestige and government power, combined with the body of a cosmopolitan female with personal knowledge of the world, it had a 'transgressive potential of one who travelled the world, symbolically contained in a uniform of professionalism' and metamorphosed the wearer from 'girl-next-door' to a 'worldly sophisticate'. ${ }^{115}$ Naheed Talat was so attracted to the uniforms that she wanted to join the airline. As she recalls,

\footnotetext{
Ah, why I wanted to join - I always used to love the uniform and, in those days, new uniforms were being purchased and I saw the photographs. It was the only airline and organisation where women were going, either nursing or PIA. So that fascinated me. I said to myself; those girls look very smart! Travelling all over the world. ${ }^{116}$
}

In this early period of PIA's history, the influence of the western-style of dress is quite evident. This is not surprising given that Pakistan emerged out of British rule in 
India and the western-style of dressing had permeated into various levels of society, business and industry. Additionally, western-style dress was also conflated with modernity and progress and so the early uniforms worn were very 'western'. Moreover, many of the staff during the initial days were foreigners on loan, until the local staff could takeover. During 1954-6, in the transitional phase from the Orient Airways to PIA, the uniform that stewardesses wore comprised of a skirt, jacket and blouse with a matching cap. Following this a new uniform was jointly designed by the well-known Pakistani dress designer Laila Shahzada, along with Chausie Fountainer, an American woman of French descent, who as a cabin crew trainer was with PIA on a five-year deputation from Pan Am. ${ }^{117}$ This design utilised the national dress and the national colours and the stewardesses wore a white shalwar with a green shirt with white cuffs and collar, complete with a dupatta. ${ }^{118}$ They also wore a green cap, remembered quite fondly by former members of staff. The cap, in many ways, retained the western-colonial influence, until the uniform was re-vamped in 1960 by Feroze Cowasji.

Initially, PIA's staff were trained by their Pan Am and BOAC counterparts. Stewardess colleges in US trained foreign women to become 'modern' through American cosmetics and grooming practices. Pan Am's college had an 'image improvement' course for beauty secrets. ${ }^{119}$ An article appearing in Pan Am's inflight magazine, Clipper, 'Girl on a Frontier' (1961), praised an American-born Pan Am stewardess, who served as a chief hostess advisor for PIA. The article commended the stewardess, for helping to 'unveil the modern world of jet travel for a young and growing Eastern nation'. The American stewardess went on to say that 'only a generation ago Pakistani women were not permitted to appear in public without a veil or to work outside their own homes', and she was proud to announce that under her supervision Pakistani girls had 'changed their 
long veils for the native uniform of PIA'. ${ }^{120}$ The message here was clear that the unveiling of women equated with modernity and progress, a message also expressed by many Pakistanis, especially evident in English newspapers like the Pakistan Times. However, this was still a largely elite activity, the fact that much of the advertising was in the English press suggests that the message was aimed only at certain segments of the market. Nevertheless, it was also a reflection of the 'middle class' and 'progressive' aspirations espoused in the Ayub-era.

Although empires had come to an end, the tactics used by the Americans during the Cold War were surreptitiously imperialistic and hegemonising. They were exporting an image of the American culture, which was sold as the 'one world culture'. ${ }^{121}$ This was reflected in the cultural and social aspects of marketing and branding, especially in the context of globalisation and served as an example of 'soft power' at work. ${ }^{122}$ Thus, when Chausie Fountainer was on deputation with PIA, she represented America and the 'free world'. It was a subtle way in which the American stewardess, "civilized the "uncivilized" women of the world by teaching American beauty secrets... delivering American beauty products' and thus becoming the 'dominant trope in U.S. airline publicity during the postsputnik jet era' ${ }^{123}$ This was particularly important, as Pakistan shared borders with a communist China and a formally non-aligned but 'pro-Soviet' India. ${ }^{124}$ Having the support of the military regime under Ayub Khan in this 'cultural Cold War', ${ }^{125}$ was considered crucial to containing communism in the region. The language and perceptions of 'the other' are clear in the implicit superior-inferior relationship with America and how it planned to teach the Third World on how to become 'civilized women'. By 'teaching foreign women how to be more feminine, according to American notions about 
womanhood, American stewardesses were positioning a particularly American model of femininity as the universal standard'. ${ }^{126}$

This universal (American) standard though was increasingly, being clothed in the national dress in airlines, so as to sell their own brand of nationality abroad and this was reflected in the dresses worn by the air-hostesses. Concomitantly, international airlines were using the national dress to customise their routes. As early as 1958, Indian and Pakistani girls who were training as BOAC stewardesses were getting a 'newly-designed sari which may be worn by them on Far Eastern routes'. ${ }^{127}$ Not just that, the airline announced that Norman Hartnell, designer to HM The Queen, had been consulted on the choice of fabric - pure silk - and colours: 'marina green with gold borders'. ${ }^{128}$ Following suit, a national competition was held in Pakistan to design new uniforms for different categories in early-1960s. Yasmin Akhtar, who entered the competition having seen its advertisement, won in one of the categories, having come through the regional round in Lahore. She remembers that when the officials calculated the amount, which was to be spent on uniforms, "it was coming too much...so they decided that the same uniform should be for everybody'. ${ }^{129}$

This 'same uniform' was designed by the French designer, Pierre Cardin, who elevated PIA and its air-hostesses on the international scene. It was ultimately Cardin's designs' that captured the imagination of the PIA brass and the public, nationally and internationally. 'Raving' notices appeared in the Paris fashion magazines. Madame Nicole Alphand, who was rated among the best-dressed women in the world and whose husband was the French Ambassador in Washington, said that the new uniform easily made the PIA air-hostess the best-dressed in the airline industry. ${ }^{130}$ The British magazine, Women's Own published an article in September 1967, titled 'Women in Uniform', which 
exclaimed thus: 'Just look at what the bosses of the Pakistan International Airlines did, for instance. They called in the famous Paris couturier, Pierre Cardin, to dream up a fabulous uniform for their hostesses - the kind of thing rich women pay hundreds of pounds for!' 131 The 'high culture' of Paris was the epitome in fashion, glamour and sophistication and PIA had scored with all these. Pixy remembers these uniforms as beautiful and practical:

The Pierre Cardin uniforms were never that type of uniforms which stayed up...no matter how high you lifted your arms, your uniform just fell...Always glamorous, sophisticated and never had problem... We had to have one colour, it was [a] very easy uniform. ${ }^{132}$

The design specification given to Cardin had not been easy, as it had to reflect the tradition and culture of Pakistan, be smart and fashionable, and, yet fit and be practical for a working girl. In 1971, Mohsin Ali described the Pakistan girl as 'a rare combination. She harbours in her dark, lustrous eyes, the unfathomable mystery of the orient, the wisdom of the ages and the easy practicality of the jet age. In this, the PIA air-hostess is a true representative of her country'. ${ }^{133}$ Out of this amalgam of the ancient and the modern, emerged a design by Cardin, which is even today considered chic and reflecting the heyday of PIA. Importantly, the Cardin designs are considered the first of their kind to utilise and reflect the national dress in the airline industry. If adopting the western dress in the colonial period by the educated elite was a sign of acceptance, collaboration and modernity, PIA's uniform was now used to exert its independence from colonialism and hark back to its own history. However, this uniform, used from November 1966, was not accepted without the raising of a few eyebrows in the public. 
The Pakistan Times called the outfit 'certainly a bombshell for our conservative tastes'. It accepted the uniform as 'extremely smart and modish' but questioned its authenticity. It argued how 'this dress, which looks more like a manly sophisticated lounging suit from "Vogue" than anything else, [was] representative of Pakistan? Would not a Swati "kurta" with a "tang pajama", for instance, have reflected more sincerely what women in our country have worn down the [ages]'. ${ }^{134}$ Nonetheless, although many of the girls came from conservative backgrounds, the new uniform became 'a fashionsetter on many college campuses' and it certainly did much to capture the imagination of young girls, who started to think about a career with the PIA with great enthusiasm. ${ }^{135}$

\section{'That Dainty Little Hat'}

Glamour, charm and allure comprised the marketing tools of the aviation industry. Their women were admired for their beauty, bravura and professionalism. PIA's advertising comprised such appealing visual representations, which were aimed at women and which shaped their meanings for them. ${ }^{136}$ That many of those who started working for PIA did so because of the alluring advertisements is amply borne out in the personal testimonies that were collected from former PIA employees. Pixy remembered one of her parents' friends, who was in the airline: 'She used to tell us all about the airline and how she had gone all over the world. It was very fascinating and very glamorous and this job at that time was considered one of the best jobs, a girl could have'. The women also allude to the fact that whilst, they were interested in responding to the advertisements and taking this opportunity, their respective families were less enthusiastic about this. Pixy's 'parents were not against it because being in the army, they were more open minded but $90 \%$ of 
the girls' parents had objections about it'. ${ }^{137}$ Naheed Talat remembers about how her family responded:

In those days, going for this sort of an unconventional profession, it was very difficult for people to accept. My family reacted badly, my mother was quite upset, and uncles were very annoyed with my father. We had quite the religious background. But my father was very supportive and said that if [she] has decided and wants to go, from my side it is okay. ${ }^{138}$

For families, 'public mobility became the source of prestige and shame'. ${ }^{139}$ Naheed's family were concerned as to 'how long [she] used to stay out of the house, girls were not even allowed to stay at their relatives' houses. Imagine them going to London or America. What will everyone say?' ${ }^{140}$ Pixy elaborated that 'a lot of girls used to have a lot of problems to convince their families that they [remained] dignified...People were jealous...they used to say cruel things like it was just waitresses' job...my mother, in turn, said that she has to work no matter what.' ${ }^{141}$ An article in the Pakistan Times from 1967 provides wonderful insights into 'The life of an Air-hostess'. Nilofer, a well-known name in PIA, had been with the airlines for ten years and was considered as one of their best air-hostesses. When she had joined, only half of the air-hostesses were Pakistani; the other half being foreigners. Training also only lasted for two weeks of grooming rather than the three months that was expected. The women who came to work for PIA were not just women who had to work but women who were educated, ambitious and from ‘respectable' families. Nilofer was no different. After finishing school from St Mary's in Sukkur (Sindh), she wanted to go into journalism and even took a correspondence course in short story writing, before an advertisement in the Pakistan Times decided her career: 
Looking back, I am not sorry I joined the Airlines. I could not have done better. I was happy I was selected as an air-hostess. But my mother was stunned and my father objected. I come from a purdah-observing Syed family. When I was selected, I had seven days of weeping and three days of starvation.

Nilofer, like many other girls, defied her family and chose to join PIA. However, aware of attracting any unsavoury attention, she remained shy of publicity and did not want her picture in the newspaper. Her tenacity and determination nonetheless comes across as she says, 'I am not educated enough, and I sometimes feel kind of left out when I look at other members of the family.' But, then, she rationalises, 'I had a squeak of stubbornness in me to get out. I just wanted to get out. At that time, I did not know what the job of air-hostess meant'. Here, one can see the mixed bag of femininity and feminism that Kathleen Barry shows so well, when she "takes the "feminine" part of the stewardesses' job seriously, giving thought and attention to the ways in which ideas about glamour were conveyed, naturalized, and produced'. Glamour, then, 'was a double edged sword for women, giving them satisfaction even as it played down the idea that being a flight attendant was "real" work' ${ }^{142}$ Similar to Nilofer, Naseem Feroze, joined PIA after seeing an advertisement in 1956 in the Pakistan Times, encouraged by her brother to apply despite her concerns about her traditional family.

The interviewing panel included Chausie Fountainer and during the interview Naseem was asked if she would consider cutting her hair, and whether she would be comfortable wearing a skirt, the then-standard attire. Despite or perhaps because of her 'refusal to give in' on both counts, she was chosen to model the new PIA uniform. It comprised 'a green tunic, green hat, white shalwar and dupatta, black shoes and purse...At all the international airports, the 'PIA Girl' uniform stood out'. ${ }^{143}$ This 
immediate recognition of the uniform and, by extension, the country was an important and proud marker of identity. As we saw above, in the Cold War context, the all-American female notion of beauty was exported around the globe via its airlines and here was PIA attempting something similar for Pakistan. As shown by Christine Yano, this was another case of 'personal dreams for upper mobility dovetailing with the era's corporate and national aspirations'. These recollections of former airhostesses bring together the airline's recruiting practices, 'which intertwined exotic cosmopolitanism and Cold War culture of competition'. ${ }^{144}$ Finally, from divergent contexts, the dimension of being 'ambassadors overseas, invited to all the diplomatic functions, meeting the locals, seeing the world', ${ }^{145}$ comes across. To continue in the words of Naseem:

\footnotetext{
They were the real brand ambassador for the country. Once President Ayub Khan travelled from London to Karachi and had a stopover at Beirut. The visitor's gallery was full of people clapping while he de-planed. Afterwards, I also de-planed. To my astonishment, there [was] vigorous clapping for me. I waved [with] resounding applause. Such was the power of the green uniform. Back on the aircraft, the President appreciated [our] work as shining example of a new country. ${ }^{146}$
}

In another interview Roohi Parveen, who had also met Ayub Khan during one of the trips, explained how she came to join the PIA in $1967 .{ }^{147}$ She was the eldest in the family, came from Bannu in the North-West Frontier Province and belonged to a Pathan family. She had completed her exams and was waiting for results when she came across the advertisement in the newspaper. With her mother's encouragement, she went and was selected from around 1,200 girls. She sketched the selection process, in which a board of five men, after asking her routine questions about her family, 'wanted to see how I walk, 
behave and talk', apart from her 'weight [and] height'. Roohi was offered the job but her mother now had second thoughts. Eventually, they cobbled a compromise in that she could work 'with ground staff, [for] eight hours and could come home in the evenings'. With a pick-up facility available, she 'joined Chaklala airport in Rawalpindi, which is now Islamabad airport'.

Reminiscing about her days with PIA, she showed pictures of her time with them. These included a promotional picture of Roohi in the Pierre Cardin uniform and meeting dignitaries at Chaklala airport. On occasions, she also went to Peshawar at the American base and had opportunities to mingle with the personnel there. As she recalls, 'they were all Americans but never misbehaved with me; instead they always addressed me very respectfully'. She goes onto highlight the importance of making eye contact and 'to speak to them with confidence'. ${ }^{148}$ This, of course, came with the training that the staff were given in how to deal professionally with the public, especially foreigners. Pixy remembers that what the airline 'expected from us was to be really professional'. ${ }^{149}$ An aura of mystique surrounded these 'slender, young and single women chosen for their scrutinized respectability, conversational skills, and style', which would be identified with this career for years. ${ }^{150}$ Thus notwithstanding the ample historically constructed stereotypes of women, western sexual ideology and nostalgic femininity, it is pertinent to note as Christine Yano does in her work that these 'women rarely saw themselves as victims'. ${ }^{151}$ This cosmopolitanism in the formative years of Pakistan's history is evident in the way it is recollected by both the public and staff who worked for PIA. As Naheed says, 'whatever I could expect from my field, [I got]. I used to go on almost all the V.V.I.P flights. I have travelled with Zulfiqar Ali Bhutto, Yahya Khan and once with Ayub Khan. I have a picture of Zia-ul-Haq on which he personally signed'. ${ }^{152}$ Syed Afaq Rizvi, who 
worked as a pilot for PIA over the period 1956-82, talks fondly about the early days and stresses on the motif of PIA being a mini Pakistan. ${ }^{153}$ The uniforms are again mentioned, bringing together the hybrid culture of East and West, the salwar kameez with a 'dainty little hat', as he recalls. However, Rizvi makes two important points, which were crucial as a catalyst in turning Pakistan into the state that we know today. First, the 1971 war in East Pakistan and the secession of Bangladesh as an independent country. PIA earned a lot from this route and the subsequent loss of traffic proved costly for it. The aviation historian, R. E. G. Davies, argues that the split effectively cut in half PIA's traffic. ${ }^{154}$ Second, by 1977, PIA had stopped serving alcohol on their flights.

The point is not one of drinking so much as of the fact that while previously PIA operated as a successful international carrier, now it was asserting itself as an 'Islamic' airline. Rizvi talks about how the first thing passengers heard was the 'safar ki dua' (for safe passage) prayers that are said at the start of the journey, and this immediately signalled to the foreigners travelling that this was an Islamic carrier. This loss of revenue from the break-up of Pakistan and this shift towards a more Islamic identity represents the wider identity crisis, which takes Pakistan on a very different trajectory from the mid1970s. ${ }^{155}$ While the tendency of the Pakistani state to turn towards Islam can be said to have been present from 1947, it was hardly a teleological tale. Instead, it has been rightly called 'a story of contingencies, contradictions, breaks and spikes' through the Ayub, Bhutto and Zia regimes. These internal contestations were overlain by the general Cold War context - where Islam was looked upon in Washington as 'an effective politicoideological bulwark against communism' - and the particular moment of 'the US's proxy war in Afghanistan', which legitimised 'violence in the name of Islam' in Pakistan. ${ }^{156}$ 
This contrasts with the 1950s and 1960s wherein the hopes for and ambitions of PIA and, by extension, the nation-state's were akin to 'a form of postcolonial cosmopolitanism... a combination of political conservatism with personal liberalism'. ${ }^{157}$ In the memories of Pixy, Bhutto's 'last days' and Zia's first serve as a break in her narration of PIA being 'a Pakistani airline but [with] most of the passengers [as] foreigners...' ${ }^{158}$ She never forgot her first foreign trip, to London, and 'walking down Oxford Street'. Working for PIA took her 'all over in New York and Paris'. She considered herself lucky and blessed that she 'joined the airlines and saw so much'. She 'got to live' then and 'now fights for the girls, who are not getting so much'. This sense of loss, not merely of personal desires or professional opportunities but of progressive values and a 'modern' future, at the religious altar of revivalism, can be read as part of a broader national 'historical failure'. ${ }^{159}$ As Pakistan takes a conservative turn, she gamely tries to make women around her "realise what their rights are and what they must do themselves and how much ability they have inside them'. ${ }^{160}$ Thus, from helping in 'consolidating the nation-state' and harnessing Ayub Khan's 'decade of development', the PIA and its women, like Pakistan itself - after flirting with Bhutto's 'authoritarian populism' - fell under 'the long shadow of Zia's military theocracy'. ${ }^{161}$

\section{Conclusion}

On the tenth anniversary of Pakistan, 14 August 1957, Zafarul Ahsan, General Manager of PIA, outlined 'plans for increased capacity'. Calling Pakistan, a nation 'born in the air age striving, as a modern nation, to maintain national unity in a territory separated by over a thousand miles of foreign land', Ahsan emphasised that it was 'not a nebulous role 
which P.I.A. plays in Pakistani national life. Nothing could have been worse than isolation for the cultural development and the expansion of the economy of the two wings'. ${ }^{162}$ It is perhaps for this reason that Jinnah was working on establishing an airline, even before Pakistan was established. The timing for Pakistan's emergence as a nationstate coincides with the airlines just beginning to take off during the 1940s and, not long after, the jet-age would revolutionise air travel. Indeed, air travel can be seen as a significant symbol of post-colonial nationhood. In turn, soon PIA was being regarded as Asia's best airline and through the 1960s and early 1970s, it 'stood strong and proud, awarded on multiple occasions and being a constant on the list of top ten airlines of the world'. ${ }^{163}$ Alongside, foreign travel filtered down to the middle classes, from being an elite activity. The nascent tourist industry was also attracting people to visit Pakistan; while a domestic market emerged, based not just on travel between the wings of Pakistan but beyond. It also opened opportunities for women to work and explore the world. At a time when women were restricted to largely working in 'respectable' jobs like teaching or medicine, thereby giving rise to a 'vast opportunity gap' vis-à-vis men, ${ }^{164}$ there was PIA, making the idea of working in the airline industry and as airline hostesses a respectable profession, thus providing 'career openings for Pakistani women'. 165

Working for PIA meant that many women were working away from home and representing Pakistan abroad. A recent Global History of the Airline Hostess lists 'registered nurses' in the 1930s, 'wives-in-training' in the 1950s, 'successful marketing tools' in the 1960s and 1970s and 'custodian of safety and service' today as the multifarious categories of the unique history of this dynamic industry pioneered by women. ${ }^{166}$ To this can be added, national representatives, as seen not only in the case of the PIA women. Although the spaces created by/for women were small during the 1950 s 
and 1960 s and there were structural limits to any 'functional equality', ${ }^{167}$ it was no small feat to make a job of an air-hostess reputable in a traditional society. Though they faced opposition from their families, many educated women from conservative families and others, looking for opportunities to work and travel, joined PIA, attracted by its creative advertising. This, in turn, was made possible by the needs of PIA to employ women to tap into the glamour quotient associated with the profession. Through the PIA advertisements and as their personification, women were visible in public spaces as glamourous yet accepted, independent yet homely at the same time, much like the latest analysis of the complicated relationship of Feminism and Flight Attendants, which invokes glamour and gender discrimination, unflagging pride and enthusiasm despite being 'waitresses in the sky'; 'sexualized in the sixties' yet 'visible symbols of social change'. ${ }^{168}$

It was an era, when Pakistan state's 'identity' and 'governmentality' seemed to go hand-in-hand with 'modernity' and development; when 'the politics of modernity' held an upper-hand over 'the practices of piety'. ${ }^{169}$ PIA flew high and prospered, some women broke new ground and travelled around the world. Their lives provide a prism with which to look at the shifting sands of their nation-state. A country, usually construed as conservative, saw an unusual challenge confronting its customs regarding the place and functions of women, in the form of the personality of the 'air-hostess'. It was a break-out moment that was international, modern even if brief and at the heart of it was a pushing of boundary for working women with all its inherent limitations and contradictions. They make it more and not less fascinating. No wonder then that there remains a sentimental and not sceptical remembrance for this age that promised so much. 


\section{Acknowledgements}

I would like to acknowledge and thank the Gerda Henkel Foundation (GHF), whose research grant made this project possible, Rana Saleem from the National Documentation Wing, Islamabad and to the anonymous reviewers who provided immensely thoughtful and valuable feedback. I would also like to thank Rakesh Ankit, Ian Talbot, Ilyas Chattha, Umber Bin Ibad and Khola Cheema for providing valuable feedback and support in this research.

\section{Notes}

\footnotetext{
${ }^{1}$ Seven interviews were conducted with former female employees of PIA. This was part of a larger project funded by GHF.

${ }^{2}$ David Willmer, 'Women as participants in the Pakistan movement: Modernization and the promise of a moral state', Modern Asian Studies, 30: 3 (1996), 573-590.

${ }^{3}$ An exception being Khawar Mumtaz and Farida Shaheed, Women of Pakistan: Two Steps Forward, One Step Back? (London, 1987).

${ }^{4}$ See Farzana Shaikh, Community and Consensus in Islam: Muslim Representation in Colonial India, 1860-1947 (Cambridge, 1989).

${ }^{5}$ See Ayesha Jalal, The Struggle for Pakistan: A Muslim Homeland and Global Politics (Cambridge, 2014).

${ }^{6}$ Saadia Toor, The State of Islam: Culture and Cold War Politics in Pakistan (University of Chicago Books, 2011), 1 .

${ }^{7}$ See Naumana Kiran, 'Political Awareness among Women in the Punjab: A case study of their role in the Pakistan Movement', Pakistan Journal of Women Studies, 20: 2 (2013), 51-79.
} 
${ }^{8}$ See Ayesha Jalal, The Sole Spokesman: Jinnah, the Muslim League and the Demand for Pakistan (Cambridge, 1985) and M. Reza Pirbhai, 'Pakistan and the Political Awakening of a Muslim "New Woman" 1937-1947', Hawwa: Journal of Women of the Middle East and the Islamic World, 12: 1, 1-35.

${ }^{9}$ See Shahida Lateef, Muslim Women in India: Political and Private Realities, 1890-1980s (London, 1990).

${ }^{10}$ See Begum Jahanara Shahnawaz, Father and Daughter: A Political Autobiography (Karachi, 2002); on Fatima Jinnah, see M. Reza Pirbhai, Fatima Jinnah: Mother of the Nation (Cambridge, 2017).

${ }^{11}$ See Pippa Virdee, 'Negotiating the Past: Journey through Muslim Women's Experience of Partition and Resettlement', Cultural and Social History, Volume 6, Issue 4 (2009), 467-84 and Faisal Devji, Muslim Zion: Pakistan as a Political Idea (Cambridge, 2013).

${ }^{12}$ See Toor, The State of Islam, 1-2.

${ }^{13}$ See Ilyas Chattha, 'After the Massacres: Nursing Survivors of Partition Violence in Pakistan Punjab Camps', Journal of the Royal Asiatic Society, Series 3, https://doi.org/10.1017/S1356186317000694 (accessed 09 January 2018).

${ }^{14}$ See Ayesha Jalal, 'The Convenience of Subservience: Women and the State of Pakistan', in D. Kandiyoti (ed.) Women, Islam and the State (Basingstoke, 1991), 77-114.

${ }^{15}$ See Parneet Hayer, Women in Colonial Punjab (1901-47), unpublished PhD. Thesis, Punjabi University (Patiala, 2010).

${ }^{16}$ See Anita Weiss, Walls Within Walls: Life Histories of Working Women in the Old City of Lahore (Boulder, 1992).

${ }^{17}$ Keith Lovegrove, Airline: Identity, Design and Culture (London, 2000), 34.

${ }^{18}$ See Alan Baumler, 'Aviation and Asian Modernity 1900-1950', Asian History (June 2017), Oxford Research Encyclopedias (accessed 6 November 2017).

${ }^{19}$ Kathleen Morgan Barry, Femininity in Flight: A History of Flight Attendants (Durham, 2007), 1.

${ }^{20}$ Some of the advertisements used in the article are available on an unofficial website about the history of PIA. Some other advertisements come from Pakistani newspapers (English). For yet others see, http://historyofpia.com/ (accessed 7 February 2016). 
${ }^{21}$ See Daniel Pope, 'Making Sense of Advertisements', from the Making Sense of Evidence series on

History Matters: The U.S. Survey on the Web, located at http://historymatters.gmu.edu, (accessed 22

August 2017), 1-16.

${ }^{22}$ See Ammara Maqsood, The New Pakistani Middle Class (Harvard University Press, 2017).

${ }^{23}$ Lovegrove, Airline, 17.

${ }^{24}$ Arjun Gunaratne and Anita M. Weiss (eds.) Pathways to Power: The Domestic Politics of South Asia (Lanham, 2013), 179.

${ }^{25}$ Christine R. Yano, Airborne Dreams: "Nisei" Stewardesses and Pan American World Airways

(Durham, 2011), 2.

${ }^{26}$ Yano, Airborne Dreams, 7.

${ }^{27}$ Ibid. 10.

${ }^{28}$ Review of Yano, Airborne Dreams, https://muse.jhu.edu/article/515815 (accessed 23 December 2017).

${ }^{29}$ Ed Mack Miller, 'Pakistan International Airlines: Great People to Fly With,' Flying (March 1963), 42.

30 'PIA is flying high', Pakistan Times, Independence Supplement, 14 August 1960.

${ }^{31}$ See Khushwant Singh, Train to Pakistan (New York, 1981; first edition, 1956).

${ }^{32}$ Enver Jamall, 'Birth of a Nation, Birth of an Airline: The History of PIA' in John Motum (ed.), The

Putnam Aeronautical Review, Volume Two (London, 1990), 218.

${ }^{33}$ Yano, Airborne Dreams, 33, 36.

${ }^{34}$ Jamall, ‘Birth of a Nation', 218.

${ }^{35}$ Based in Calcutta and benefitting from their trade in indigo, tea, jute, and else, the Ispahanis, with a branch in London, had participated in the Khilafat Movement in the early-1920s, set-up the 'New Muslim Majlis' in Calcutta in early-1930s and were involved in Calcutta Corporation, afterwards. See Kenneth Macpherson, The Muslim Microcosm: Calcutta, 1919-1935 (Wiesbaden, 1935, 1972), 121; also see ZH

Zaidi, MA Jinnah-Ispahani Correspondence - 1936-1948 (Karachi, 1976).

${ }^{36}$ Shahrukh Afsheen, Under Five Flags: Life Like a Turbulent River Flows (USA, 2011), 64.

${ }^{37}$ M. A. H. Ispahani, Quaid-i-Azam Jinnah as I Knew Him (Karachi, 1966, 1976), 130; also see, Naureen Talha, 'Indian Muslims in British India: Toward Economic Nationalism and Economic Independence (1943-1947)', Islamabad: Institute of Strategic Studies, http://www.issi.org.pk/publicationfiles/1299570865 79925501.pdf, (accessed 7 February 2016), 13. 
${ }^{38}$ https://www.flightglobal.com/pdfarchive/view/1939/1939\%20-\%201264.html (accessed 23 December 2017).

${ }^{39}$ http://www.tata.in/aboutus/articlesinside/How-the-Maharaja-got-his-wings (accessed 24 December 2017). Also see R. M. Lala, Beyond the Blue Mountain: A Life of JRD Tata (Delhi, 1993), 91-97, 113-16, 128-32, 145 and 149-50.

4012 September 1946, File No. 17 (38)/48-PMS, National Archives of India.

${ }^{41}$ Ispahani, Quaid-i-Azam Jinnah as I knew Him, 132

${ }^{42}$ Jamall, 'Birth of a Nation', 220; also see http://www.piac.com.pk/PIA_About/pia-about_History.asp (accessed 22 August 2017).

${ }^{43}$ Jamall, 'Birth of a Nation', 220

${ }^{44}$ See http://www.historyofpia.com/history.htm (accessed 22 August 2017).

${ }^{45} \mathrm{http}: / /$ www.airwhiners.net/whine cheez/20040726.htm (accessed 1 January 2018).

${ }^{46}$ Yano, Airborne Dreams, 16.

${ }^{47} 22$ February 1960, File No. 111, Planning Commission, Government of Pakistan (GOP).

${ }^{48}$ Ibid.

493 March 1956, Folder: 125/cf/54-24, Ministry of Defence (Aviation Division), GOP.

${ }^{50}$ Folder: 125/cf/54-28, Ministry of Defence (Aviation Division), GOP.

519 May 1956, Folder: 125/cf/54-31, Ministry of Defence (Aviation Division), GOP.

${ }^{52}$ Zafarul Ahsan, 'P.I.A. Plans for Increased Capacity', Pakistan Times, 14 Aug 1957.

5314 September 1959, Folder: 125/cf/54-59, Ministry of Defence (Aviation Division), GOP. See R. E. G. Davies, Airlines of the Jet Age: A History (Washington DC, 2016).

${ }^{54}$ File No. 24 (1), Planning Commission, GOP.

${ }^{55}$ For a classic account see, Ayesha Jalal, The State of Martial Rule: The Origins of Pakistan's Political Economy of Defence (Cambridge, 1990). For a contemporary treatment, see Aqil Shah, The Army and Democracy: Military Politics in Pakistan (Massachusetts, 2014).

${ }^{56}$ See Sarfraz Husain Ansari, 'Forced Modernization and Public Policy: A Case Study of Ayub Khan Era (1958-1969)', Journal of Political Studies, 18: 1, 45-60. 
${ }^{57}$ Markus Daechsel, Islamabad and the Politics of International Development in Pakistan (Cambridge, 2015), 3; also see, Farooq Bajwa, From Kutch to Tashkent: The Indo-Pakistan War of 1965 (London, 2013).

${ }^{58}$ See Hasan-Askari Rizvi, Military, State and Society in Pakistan (London, 2000), 82-100 and Ian Talbot, Pakistan: A New History (Oxford, 2015), chapter 3.

${ }^{59}$ See W. A. Wilcox, Pakistan: The Consolidation of a Nation (New York, 1963).

${ }^{60}$ See Roby C. Barrett, The Greater Middle East and the Cold War: US Foreign Policy under Eisenhower and Kennedy (London, 2007), Andrew J. Rotter, 'Gender Relations, Foreign Relations: The United States and South Asia, 1947-1964', The Journal of American History, 81: 2 (September 1994), 518-42, Robert McMahon, The Cold War on the Periphery: The United States, India, and Pakistan (New York, 1994) and Odd Arne Westad, The Global Cold War: Third World Interventions and the Making of our Times (Cambridge, 2007).

${ }^{61}$ For a blistering critique, see Tariq Ali, The Duel: Pakistan on the Flight Path of American Power (London, 2009).

${ }^{62}$ See Dennis Kux, The United States and Pakistan, 1947-2000: Disenchanted Allies (Washington DC, 2001).

${ }^{63}$ See Farooq Bajwa, Pakistan and the West: The First Decade (Karachi, 1996).

${ }^{64}$ See Davies, Airlines of the Jet Age.

${ }^{65}$ Jamall, 'Birth of a Nation', p. 226.

${ }^{66}$ See Shuja Nawaz, Crossed Swords: Pakistan, its Army and the Wars within (Karachi, 2008).

${ }^{67} 4$ August 1960, Folder: 73/cf/60-1, President's secretariat (cabinet division), GOP.

${ }^{68} 24$ September 1960, File No. 8 (1), Planning Commission, GOP.

${ }^{69}$ Pakistan Times, 14 August 1962.

${ }^{70}$ Pakistan Times, 20 July 1962 and 26 July 1963.

${ }^{71}$ Sam Whitworth, Chariots of Fire (Lulu.com, 2016), 311.

${ }^{72}$ Libbie Escome-Schmidt, Glamour in the Skies: The Golden Age of the Air Stewardess (Gloucestershire, 2009), 134-37.

${ }^{73}$ Ibid. 138-40.

${ }^{74}$ Yano, Airborne Dreams, 11. 
${ }^{75}$ Jamall, 'Birth of a Nation', 225; Whitworth, 311.

${ }^{76} \mathrm{http}: / /$ www.airwhiners.net/whine cheez/20040726.htm (accessed 24 December 2017).

${ }^{77}$ W. M. Dobell, ‘Ayub Khan as President of Pakistan’, Pacific Affairs. October 1969, 42: 3, 294-310.

${ }^{78}$ James Russell Andrus and Azizali F. Mohammed, The Economy of Pakistan (California, 1958), 254.

${ }^{79}$ Review of Phil Tiemeyer, Plane Queer: Labor, Sexuality, and AIDS in the History of Male Flight

Attendants (Berkeley, 2013), https://muse.jhu.edu/article/558756 (accessed 23 December 2017).

${ }^{80}$ Barry, Femininity in Flight, 96.

${ }^{81}$ Throughout this essay, I have used the term air-hostess because it was commonly used during the period covered in this research; where writers have used other terms I have retained their preference. The term emerged in 1945 when the Trans World Airline (TWA) adopted the term 'air-hostess' marking the rise of a new vision of stewardess. More common terms used today are flight attendants or cabin crew, which are gender neutral.

${ }^{82}$ Interview with Naheed Talat, 11 December 2013, Lahore.

${ }^{83}$ Maqsood, The New Pakistani Middle Class, 5.

${ }^{84}$ Interview with Rukhsana Majid (known as Pixy), 9 April 2013, Lahore.

${ }^{85}$ Escome-Schmidt, Glamour in the Skies, 22.

${ }^{86}$ See Lovegrove, Airline.

${ }^{87}$ Pakistan Times, 8 July 1962.

${ }^{88}$ Maqsood, The New Pakistani Middle Class, 6-7.

${ }^{89}$ Pakistan Times, 19 July 1964.

${ }^{90} \mathrm{https} / / / w w w . r e s e a r c h g a t e . n e t / p u b l i c a t i o n / 236710143$ _Femininity_in_Flight_A_History_of_Flight_Atte ndants_review [accessed Dec 23 2017].

${ }^{91}$ Pakistan Times, 14 October 1966.

${ }^{92}$ Victoria Vantoch, The Jet Sex: Airline Stewardesses and the Making of an American Icon (Philadelphia, 2013), 42

${ }^{93}$ See review of Tiemeyer, Plane Queer, https://muse.jhu.edu/article/558756 (accessed 23 December 2017).

${ }^{94}$ Escome-Schmidt, Glamour in the Skies, 17; also see Omelia and Michael Waldock, Come Fly with Us! ${ }^{95} 31$ March 1960, Folder: 125/cf/54-65 \& 66, GOP. 
${ }^{96}$ See PIA history, http://www.piac.com.pk/pia_about/pia-about_history.asp (accessed 7 February 2016.)

${ }^{97}$ Pakistan Times, 14 August 1962; earnings grew from Rs. 813 to 1565 lakhs over 1959-62.

${ }^{98}$ Anon., 'PIA is flying high,' Pakistan Times, Independence Supplement 14 August 1960.

${ }^{99}$ Interview with Naheed Talat, 11 December 2013, Lahore.

${ }^{100}$ Yano, Airborne Dreams, 39, 41.

${ }^{101}$ Ibid.

${ }^{102}$ Interview with Pixy, 9 April 2013, Lahore.

${ }^{103}$ Vantoch, The Jet Sex, 2.

${ }^{104}$ See Walter L. Hixson, Parting the Curtain: Propaganda, Culture and the Cold War, 1945-61 (New York, 1997).

${ }^{105}$ Sara Lennox, 'Constructing Femininity in the Early Cold War Era,' in Agnes C. Mueller (ed.), German Pop Culture: How “American” is it (Ann Arbor, 2004), 66-80.

${ }^{106}$ Vantoch, The Jet Sex, 122; also see Christopher Endy, Cold War Holidays: American Tourism in France (Chapel Hill, 2005.)

${ }^{107}$ Pakistan Times, 11 September 1966.

${ }^{108}$ Interview with Naheed Talat, 11 December 2013, Lahore.

${ }^{109}$ Interview with Pixy, 9 April 2013, Lahore.

${ }^{110}$ Ibid.

${ }^{111}$ Drew Whitelegg, Working the Skies: The Fast-Paced, Disorienting World of the Flight Attendant (New York, 2007), 198.

${ }^{112}$ Camille Mirepoix, 'Careers for women in Pakistan', Pakistan Times, 16 October 1966.

${ }^{113}$ See Chandra Talpade Mohanty, Ann Russo and Lourdes Torres (eds.) Third World Women and the Politics of Feminism (Bloomington, 1991).

${ }^{114}$ See Melissa T. Brown, Enlisting Masculinity: The Construction of Gender in US Military Recruiting Advertising During the All-Volunteer Force (New York, 2012).

${ }^{115}$ Yano, Airborne Dreams, p. 41.

${ }^{116}$ Interview with Naheed Talat, 11 December 2013, Lahore. 
117 'PIA crew to get a fashion makeover,' The Daily Times, 7 March 2015,

http://www.dailytimes.com.pk/entertainment/07-Mar-2015/pia-crew-to-get-a-fashion-makeover (accessed 7 February 2016).

${ }^{118}$ For examples of uniforms from 1954-56 and 1956-60, see http://historyofpia.com/uniform1a.htm (accessed 7 February 2016).

${ }^{119}$ Vantoch, The Jet Sex, 124.

${ }^{120}$ Ibid.

${ }^{121}$ See Gregory A. Barton, Informal Empire and the Rise of One World Culture (Basingstoke, 2014), 11943 and $168-85$.

${ }^{122}$ See Joseph Nye Jr., Soft Power: the Means to Success in World Politics (New York, 2004).

${ }^{123}$ Vantoch, The Jet Sex, 122.

${ }^{124}$ Stephen Cohen, 'The Soviet Union and South Asia', in Edward Kolodziej and Roger Kanet (eds.), The Limits of Soviet Power in the Developing World (Basingstoke, 1989), 201-26.

${ }^{125}$ Toor, The State of Islam, 6.

${ }^{126}$ Vantoch, The Jet Sex, 123.

${ }^{127}$ Pakistan Times, 3 May 1958.

${ }^{128}$ Lovegrove, Airline, 17 and Escome-Schmidt, Glamour in the Skies, 121.

${ }^{129}$ Interview with Yasmin Akhtar, Lahore.

${ }^{130}$ Mohsin Ali, ‘PIA Pioneers a Revolution in Women's Fashion', Focus on Pakistan, 1: 2 (1971), 50-4.

${ }^{131}$ Ibid.

${ }^{132}$ Interview with Pixy, 9 April 2013, Lahore.

${ }^{133}$ Ali, 'PIA pioneers', 50-54.

134 'Fashion in the air’, Pakistan Times, 25 September 1966.

135 'The Life of an Air-hostess', Pakistan Times, 6 August 1967.

${ }^{136}$ See S. Abel, M. de Bruin and A. Nowak, Women, Advertising and Representation: Beyond Familiar Paradigms (Cresskill, 2010).

${ }^{137}$ Interview with Pixy, 9 April 2013, Lahore.

${ }^{138}$ Interview with Naheed Talat, 11 December 2013, Lahore.

${ }^{139}$ Yano, Airborne Dreams, 14. 
${ }^{140}$ Interview with Naheed Talat, 11 December 2013, Lahore.

${ }^{141}$ Interview with Pixy, 9 April 2013, Lahore. Also see Berry, Femininity in Flight, 96.

${ }^{142}$ https://www.researchgate.net/publication/236710143_Femininity_in_Flight_A_History_of_Flight_Atte ndants_review [accessed Dec 23 2017].

${ }^{143}$ See 1956-1960 uniforms, http://www.historyofpia.com/uniform1.htm (accessed 24 August 2017).

${ }^{144}$ See review of Yano, Airborne Dreams, https://muse.jhu.edu/article/477887 (accessed 23 December 2017).

${ }^{145}$ See Escome-Schmidt, Glamour in the Skies.

${ }^{146}$ See photo gallery of PIA's Finest Men and Women, http://www.historyofpia.com/legends48.htm (accessed 24 August 2017).

${ }^{147}$ Interview with Roohi Parveen, 8 December 2013, Lahore.

${ }^{148}$ Ibid.

${ }^{149}$ Interview with Pixy, 9 April 2013, Lahore.

${ }^{150}$ See Escome-Schmidt, Glamour in the Skies.

${ }^{151}$ Yano, Airborne Dreams, 419; https://muse.jhu.edu/article/477887 (accessed 23 December 2017).

${ }^{152}$ Interview with Naheed Talat, 11 December 2013, Lahore.

${ }^{153}$ See The Citizens Archive of Pakistan, 'Oral History Project - Pakistan International Airline', uploaded 14 November 2011; http://www.youtube.com/watch?v=zP-D7wYZyhw (accessed 7 February 2016).

${ }^{154}$ See R. E. G. Davies, Airlines of Asia since 1920 (London, 1997).

${ }^{155}$ Yasmin Saikia, 'Ayub Khan and Modern Islam: Transforming citizens and the nation in Pakistan.'

South Asia: Journal of South Asian Studies, 37: 2 (2014), 292-305.

${ }^{156}$ Toor, The State of Islam, 2-4.

157 Yano, Airborne Dreams, 15.

${ }^{158}$ Interview with Pixy, 9 April 2013, Lahore.

${ }^{159}$ Maqsood, The New Pakistani Middle Class, 6-7.

${ }^{160}$ Interview with Pixy, 9 April 2013, Lahore.

${ }^{161}$ See Toor, The State of Islam.

162 Pakistan Times, 14 August 1957. 
${ }^{163}$ Nadeem F. Paracha, 'Also Pakistan', Dawn, 9 February 2012,

http://beta.dawn.com/news/694185/also-Pakistan (accessed 7 February 2016).

${ }^{164}$ Pakistan Times, 10 November 1968.

${ }^{165}$ Pakistan Times, 5 July 1970.

${ }^{166}$ See Johanna Omelia and Michael Waldock, Come Fly with Us! : A Global History of the Airline Hostess (Collectors Press, 2006).

${ }^{167}$ Toor, The State of Islam, 6.

${ }^{168}$ See Peter Pigott, Coffee, Tea, or...? Feminism and Flight Attendants - A History (Dundurn, 2018).

${ }^{169}$ Maqsood, The New Pakistani Middle Class, 1-2. 